\title{
Phylogeny and biogeography of the genus Pelinoides Cresson (Diptera-Ephydridae)
}

\author{
MERCEDES LIZARRALDE DE GROSSO ${ }^{1} \&$ CLAUDIA SZUMIK ${ }^{2}$ \\ ${ }^{l}$ Instituto Superior de Entomología, Facultad de Ciencias Naturales e Instituto Miguel Lillo, Universidad Nacional de Tucumán and \\ Consejo Nacional de Investigaciones Científicas y Técnicas. Miguel Lillo 205, Tucumán, Argentina. E-mail: ticky@csnat.unt.edu.ar \\ ${ }^{2}$ Ibid.E-mail: cszumik@csnat.unt.edu.ar
}

\begin{abstract}
A phylogenetic analysis of the 21 species of genus Pelinoides using 44 discrete morphological characters is presented. From the previous proposed three groups, pallipes, sulcatus and cyclocerus, the first is recovered. The sulcatus group appears as paraphyletic in terms of cyclocerus. Pelinoides is present in the Neotropical and Andean Regions and in the Transitional South American Zone. Four areas of maximum endemicity were found. Eleven vicariant events are described and discussed, using the areas of endemisms and biogeographic provinces where Pelinoides occurs.
\end{abstract}

Key words: Pelinoides, Phylogeny, Biogeography, Andean and Neotropical Regions

\section{Resumen}

Se presenta un análisis filogenético de las 21 especies del género Pelinoides, usando 44 caracteres morfológicos discretos. Se recupera al grupo pallipes de una propuesta anterior que definía tres grupos: pallipes, sulcatus y cyclocerus. El grupo sulcatus resulta parafilético en términos de cyclocerus. Pelinoides está presente en las Regiones Biogeográficas Neotropical y Andina y en la Zona de Transición de América del Sur. Se determinan cuatro áreas de máximo valor de endemicidad. Se describen y discuten once eventos vicarantes usando las áreas de endemismo y las provincias biogeográficas donde está presente el género Pelinoides.

Palabras clave: Pelinoides, Filogenia, Biogeografía, Regiones Andina y Neotropical

\section{Introduction}

The shore-fly genus Pelinoides Cresson 1931 is placed in the subfamily Ilytheinae Cresson, tribe Hyadinini Phillips et al. (Mathis \& Zatwarnicki, 1995). This group is appropiate for cladistic and biogeographic analysis because it is clearly a monophyletic group, with only 21 species that are distributed in very restricted areas biogeographic provinces, ecoregions - of the Andean and Neotropical Regions and Transitional South American Zone (Morrone, 2004). Although the alpha taxonomy is fairly accurate (Cresson, 1934; Wirth, 1968; Lizarralde de Grosso, 1981, 1989; Mathis, 1977, 1985), relationships between the species are still unknown, and nothing has been published regarding the sequence of vicariant events in this genus. The only statement on the internal relationships in Pelinoides was given by Mathis (1985), who divided the genus in 3 species groups: the pallipes group, with two species (P. pallipes and $P$. andinus) distributed on both sides of the Andes in Perú, Ecuador and Colombia and, in Central America below $1000 \mathrm{~m}$ of altitude; the cyclocerus group, with a single 
species, from the O' Higgins Province in Chile; and the sulcatus group with the 18 remaining species $(P$. amblys, $P$. andinus, $P$. australis $P$. chilensis, $P$. chiloensis, $P$. colerus, $P$. flavipalpus, $P$. flinti, $P$. fuscus, $P$. nigrihalteratus, P. obscurus, P. opacus, P. penai. P. phaeopleurus, P. pruinosus, P. pullus, P. sulcatus, P. unctus) spread from the Navarino Island through temperate zones in Argentina and Chile to the highest areas in Perú and Ecuador. This is the first attempt to analyze relationships among the 21 species of Pelinoides according the morphological characters classically used in the taxonomy of this group.

Objetives of this work are to propose the first cladistic analysis for the 21 species of Pelinoides, to test the validity of species groups previously proposed, and to identify possible vicariant events, that requires not only the phylogenetic hypothesis of the group in question but also the units of study (the areas) identified. Geographic units of study were analyzed using formal and quantitative methods.

\section{Material and methods}

\section{Cladistic Analysis}

Cladistic analysis was carried out using parsimony criteria under equal weights, as implemented in the program TNT ver. 1.0 (Goloboff et al., 2005; see reviews of the program in Giribet, 2005, Hovenkamp, 2004, Meier \& Ali, 2005). The tree search algorithms used here were forty replications of a random addition sequence Wagner tree, each followed by tree bisection reconnection (TBR) branch-swapping. The group support was measured using relative Bremer Support (Goloboff \& Farris, 2001) and jacknifing (symmetric resampling of Goloboff et al., 2003).

Characters used in this study (Appendix 1) were observed in types and additional material from the Instituto-Fundación Miguel Lillo, and/or taken from the literature (Cresson 1931, 1934; Hendel 1930, Lizarralde de Grosso, 1981; Mathis, 1977, 1985; Zatwarnicki, 1992).

All characters are discrete. Stripe pattern of mesonotum, which has eight conditions (Figs.1-8), was coded in two ways: (1) as a lineal additive character with eight states, and (2) the trait was divided into six characters (see Appendix 1 for a full description). Results of both codification types are compared and discussed.

Nostima elegantula Hendel 1930 was chosen as the outgroup, and all species of Pelinoides were included in the study (see Appendix 2).

\section{Biogeographic analysis}

To identify areas we used the formal method of areas of endemism (Szumik et al., 2002; Szumik \& Goloboff, 2004); implemented in the programs NDM and VNDM ver. 2.5 (Goloboff, 2005). A data matrix for this analysis consisted of a cell grid of $2^{\circ}$ where presence/absence of each species of Pelinoides was recorded for each cell of the grid. The method evaluates, with an index, areas (group of cells) according to how well the distribution of a species to each area is adjusted. Then, those areas with maximum values are retained. One hundred records from the 21 species were analyzed (binary data matrix in Appendix 3). When the species were not part of any area of endemism, distribution was replaced by the biogeographic provinces equivalent (following Morrone, 2001; 2004). The resulting areas were scored as a unique unordered character and mapped using a down pass Fitch optimization (following Ronquist, 1994). Those nodes, that separated two or more disjunct areas, are then considered as evidence of a vicariant event.

\section{Results and discussion}

Phylogeny

Optimal trees from both types of codification of mesonotum stripes have some resolution in common (see 
consensus Fig. 9): the monophyly of the pallipes group and the paraphyly of the sulcatus group. Almost all the synapomorphies that define the Pelinoides non "pallipes" are not homoplastic (Figs. 10 and 11), namely, the absence of dorsally branching rays onto the arista (character 5), the dorso-apical angle of the first flagellomere angulated (character 6) and blackish brown femora and tibia (character 31). There is also some agreement on the apical section of the cladograms (Fig. 9): (1), the group of P. pullus and P. chilensis being supported by having a scutum with blackish stripes (character 19, Figs. 10 and 11) and the abdominal tergum less microtomentose than the mesonotum (character 34, Figs. 10 and 11), and (2) the species $P$. cyclocerus, $P$. sulcatus, $P$. amblys, $P$. phaenotus, $P$. chiloensis, $P$. nigrihalteratus and $P$. australis by sharing the sparsely microtomentose mesonotum (character 16) and the abdominal tergum more microtomentose than mesonotum (character 34, Figs. 10 and 11).

Four optimal trees (with 155 steps, CI: 50, RI: 56) are obtained when the stripes of the mesonotum are analyzed as a unique and additive character, which appears as a synapomorphy of several groups (see consensus Fig. 10). However, it is not very concordant (15 extra steps) and has some parallelisms (e.g. the state 0 present in P. pullus and the group of $P$. amblys and P. phaeonotus, or the state 1 in P. andinus and P. obscurus). Six optimal trees (149 steps longer, CI: 52, RI: 57) with the alternative codification of the mesonotum stripes (characters 39 to 44 in Appendix 1) are found. Characters 41 and 42 are the only informative ones. The partial stripes (character 41) appear perfectly adjusted to the trees and supporting the group of P. unctus and P. pruinosus. The absence of stripes on the dorsal tracks (character 42) defines the sister group of $P$. flavipalpus (Fig. 11) but the presence of this condition reappears independently three times in $P$. pruinosus, $P$. phaeopleurus, and $P$. nigrihalteratus.

There are many optimal alternatives for the position of the species $P$. phaeopleurus, $P$. colerus, P. flinti, $P$. fuscus and $P$. penai in the trees in both analyses, but this group is well supported, according to the Bremer support in the alternative codification (Fig.12). There are a few nodes that have a median support like the pallipes group (Fig. 12) and some other nodes in the apical section of the cladogram with two supports (Figs. 12 and 13). Then some relationships remain unresolved (position of $P$. phaeopleurus, $P$. colerus, $P$. flinti, $P$. fuscus and $P$. penai and position of $P$. flavipalpus, P. opacus, P. unctus, P. pruinosus). Species groups proposed by Mathis (1985) are recovered in part: in our study, the pallipes group is recovered, and sulcatus group appears as paraphyletic in terms of cyclocerus.

Hence, we propose two species groups, pallipes, like Mathis 1985, and sulcatus, for all other species (Fig. 9-13):

a) pallipes group: P. pallipes and P. andinus. Distribution: Panamá, Honduras, Guatemala, Colombia, Ecuador and Perú.

b) sulcatus group: the other 19 species. Distribution: Ecuador, Perú, Argentina, Uruguay, Chile to Navarino Island.

Biogeography

Pelinoides is distributed from Mesoamerica to the extreme south of South America. The pallipes group is distributed from Guatemala to Perú, and the sulcatus group from Ecuador to the south of Chile. The groups overlap only in Ecuador and Perú.

Eight species are found in a single locality: P. cyclocerus (Rio Claro, O’Higgins Province, Chile), P. pullus (Abra Pampa, Jujuy, Argentina), P. amblys (Parral Linares, Chile), P. chiloensis (Chepu, Chiloé, Chile), P. phaeonotus (Río Orosmayo, Jujuy Province, Argentina), P. opacus (Tucumán, Argentina), P. pruinosus (Escoipe, Salta Province, Argentina) and one in a very restricted area: P. nigrihalteratus (Osorno Province, Chile) (all of them of sulcatus group).

Four areas with maximum values of endemicity were found with NDM (Figs. 14). Area (A) is equivalent to the combined biogeographic provinces Puna / Prepuna and is defined by five species: P. fuscus, P. opacus, P. phaeonotus, P. pruinosus and P. pullus. Area (B) is the combination of the provinces of Coquimbo / Maule 
and is defined by three species $P$. chilensis, $P$. flavipalpus and $P$. penai. Area (C) is the combination of Maule / Valdivian Forest, where two species gave the endemicity score: P. penai and P. phaeopleurus. Area (D) is the Valdivian Forest defined by three species: P. chiloensis, $P$. cyclocerus and P. nigrihalteratus. We replaced the distributions of the twelve species of Pelinoides that do not give any endemicity score by the biogeographic provinces they occupy (Appendix 4). An unordered character of 14 states representing those provinces was mapped onto the ten optimal trees in the morphological analysis.

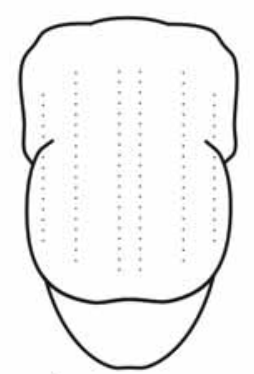

1

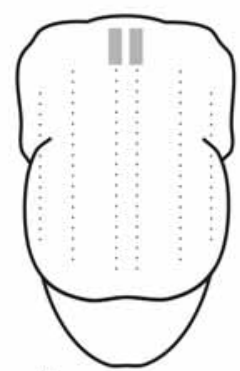

5

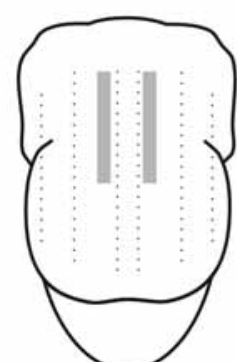

2

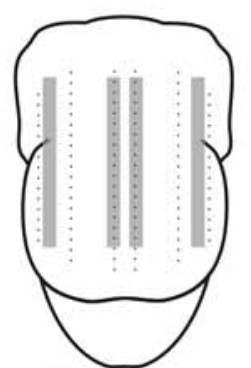

6

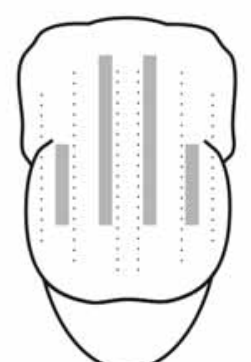

3

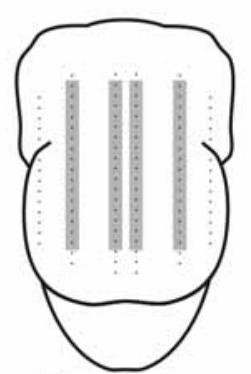

7

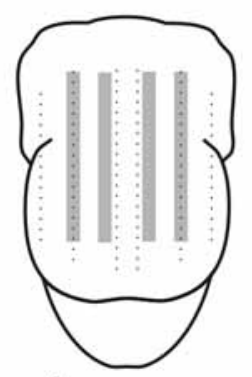

4

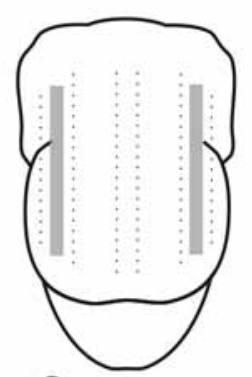

8

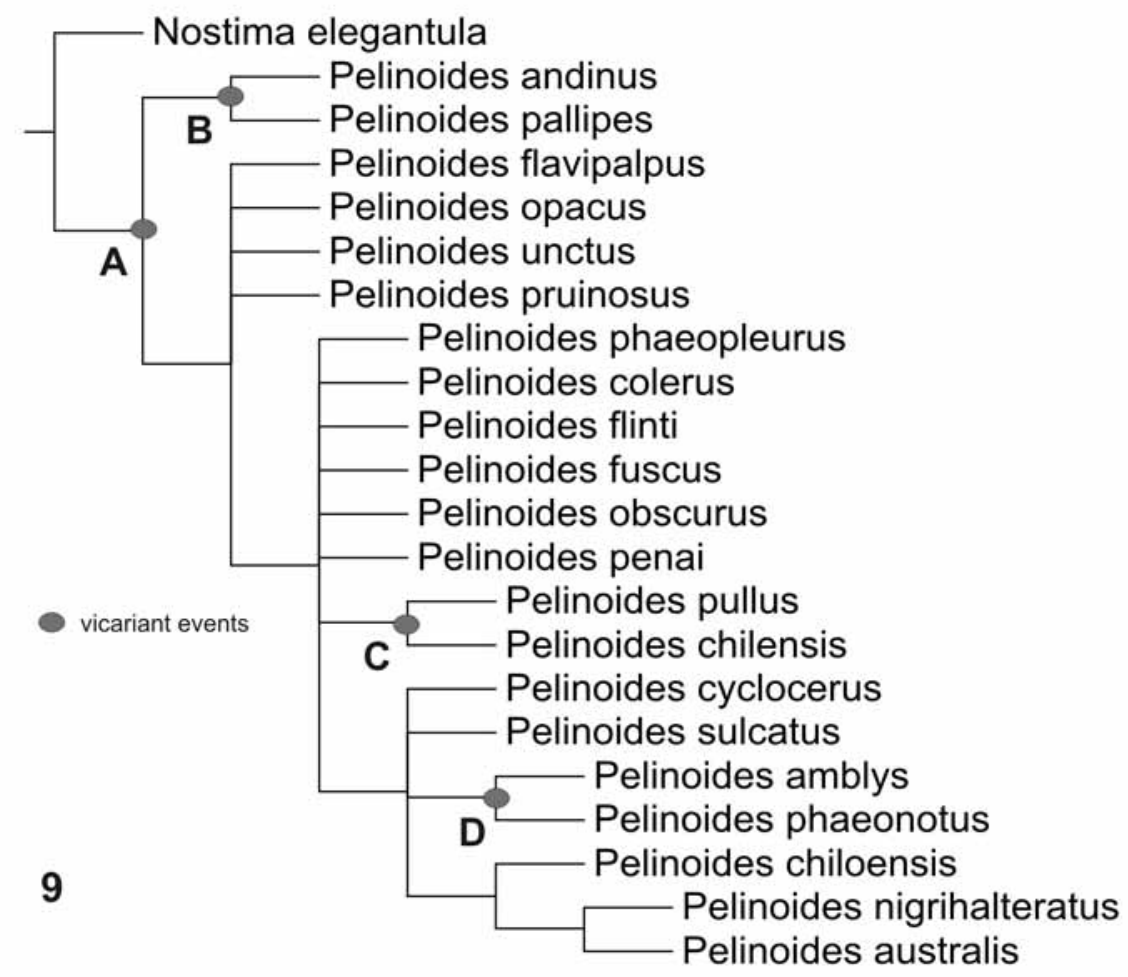

FIGURES 1-9. 1-8, Conditions of stripes of mesonotum. 9, Consensus of all trees obtained in both analyses. 


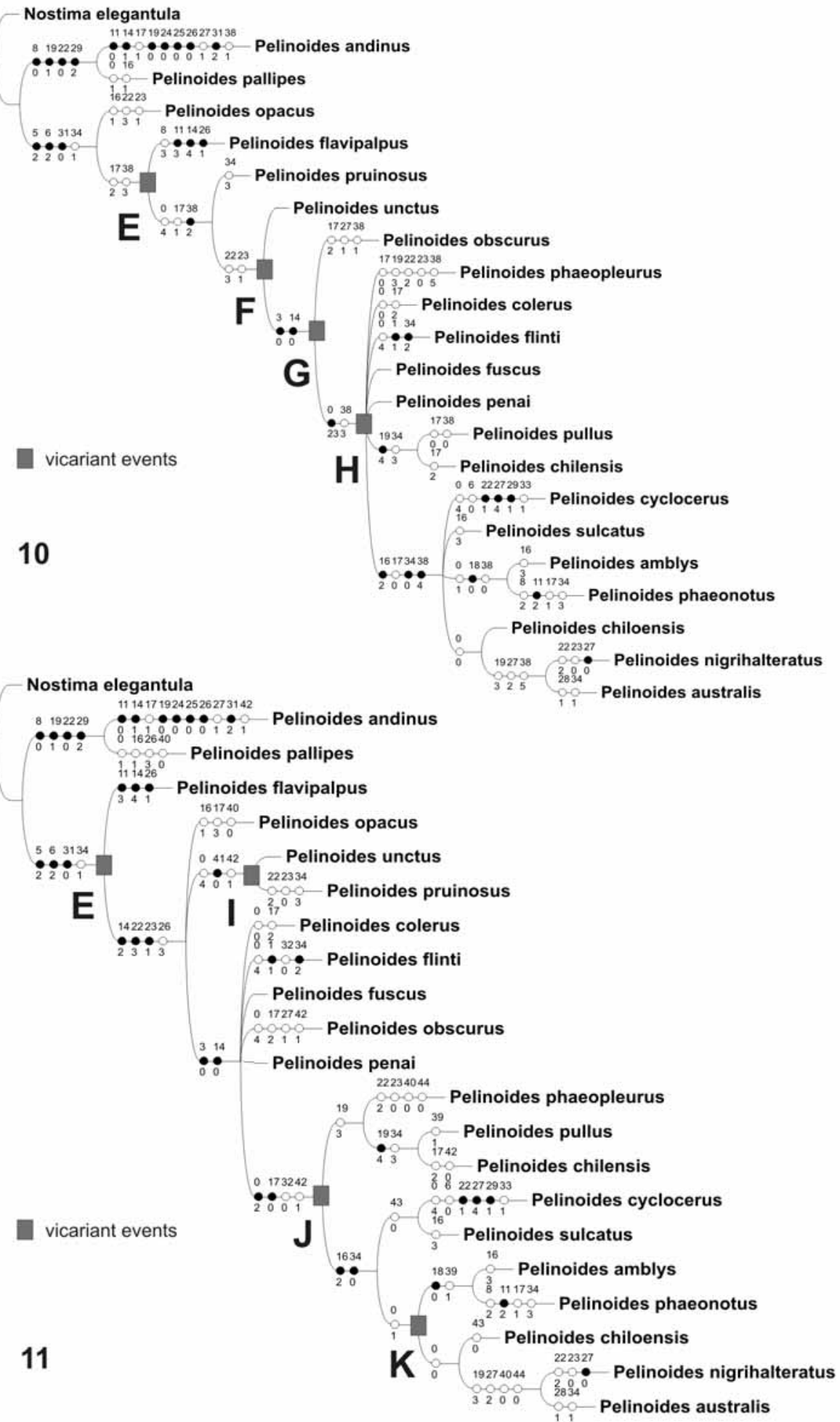

FIGURES 10-11. 10, Consensus with the synapomorphies common to the four optimal trees. (mesonotum stripes' codification I). 11, Consensus with the synapomorphies common to the six optimal trees. (mesonotum stripes' codification II).

Vicariant events common to the 10 cladograms (Fig.9, 15-25) are: A (Fig.15) (Peruvian Puna + Napo + Western Ecuador + Western Panamanian Isthmus + Chiapas) and (Argentinean Puna + Prepuna + Atacama + Coquimbo + Santiago + Maule); B (Fig.16) (Peruvian Puna + Napo) and (Western Ecuador + Western Pana 

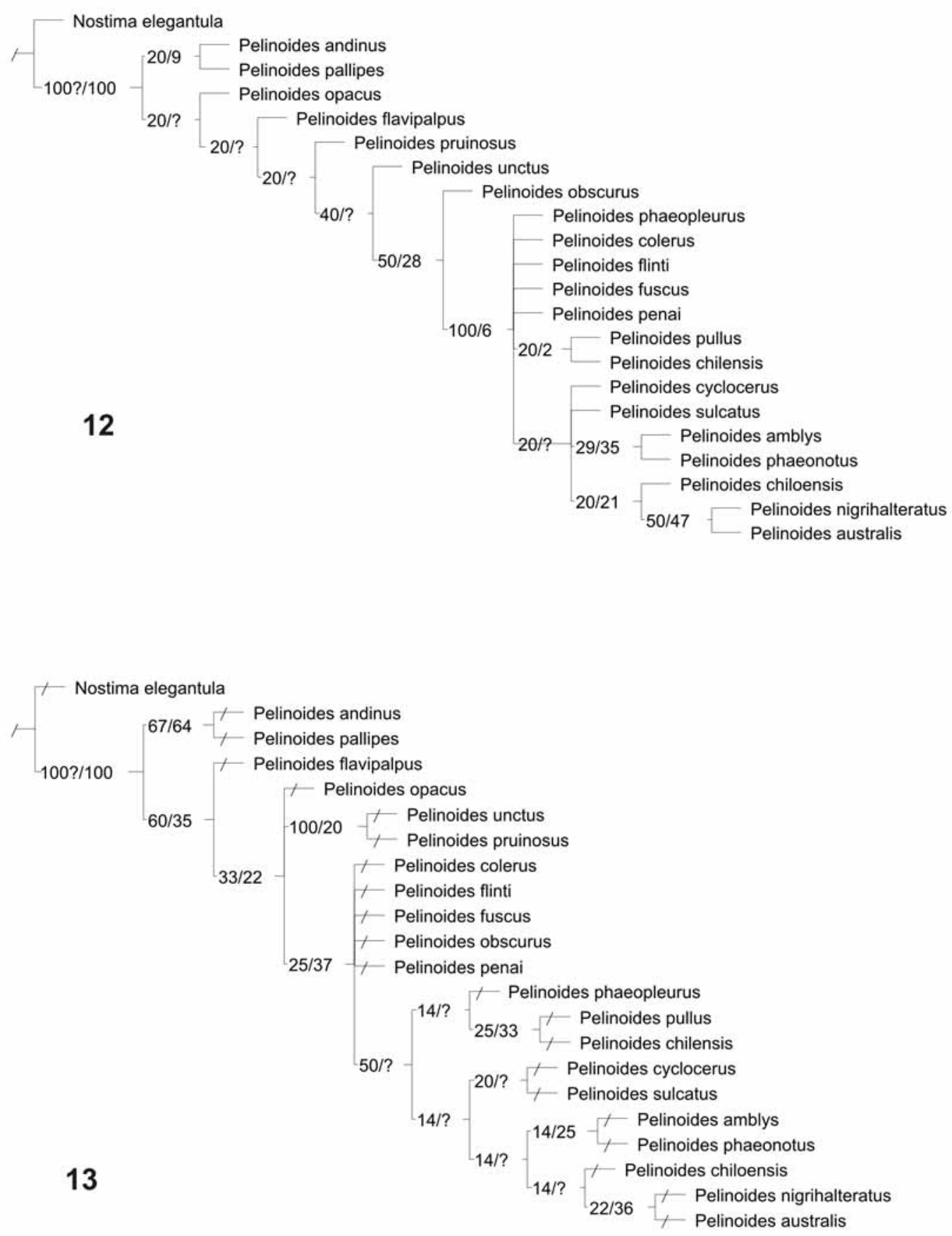

FIGURES 12-13. 12, Relative Bremer supports (from 5000 trees 6 steps longer) and Symmetric Resampling (P=33) for codification I. 13, Relative Bremer supports (from 5000 trees 6 steps longer) and Symmetric Resampling (P=33) for codification I.

manian Isthmus + Chiapas); C (Fig.17) (Argentinean Puna + Prepuna) and (Atacama + Coquimbo + Santiago + Maule); D (Fig.18) (Argentinean Puna + Prepuna) and (Maule + Valdivian Forest). The following vicariant event present in both groups of cladograms, even though the relationships among the species are not the same. Such an event (Figs.10-11, 15-25) is represented by E (Fig.19) (similar to C but present in the basal section of the cladograms) between (Atacama + Coquimbo + Santiago + Maule) and (Puna + Prepuna). Other events are present only in one cladogram group like (Figs.10-11): F (Fig.20) (Monte + Pampa) and (Norandean Paramo + Puna + Prepuna + Magellanic Forest); G (Fig.21) (Norandean Paramo + Peruvian Puna) and (Argentinean Puna + Prepuna + Magellanic Forest); H (Fig. 22) (Argentinean Puna + Prepuna) and (Magellanic Forest); I 
(Fig23), which is similar to F, (Monte + Pampa) and (Puna + Prepuna); J (Fig.24) (Puna + Prepuna + Atacama+ Coquimbo + Santiago + Maule) and (Valdivian Forest); K (Fig.25) (Puna + Prepuna + Maule) and (Valdivian Forest).
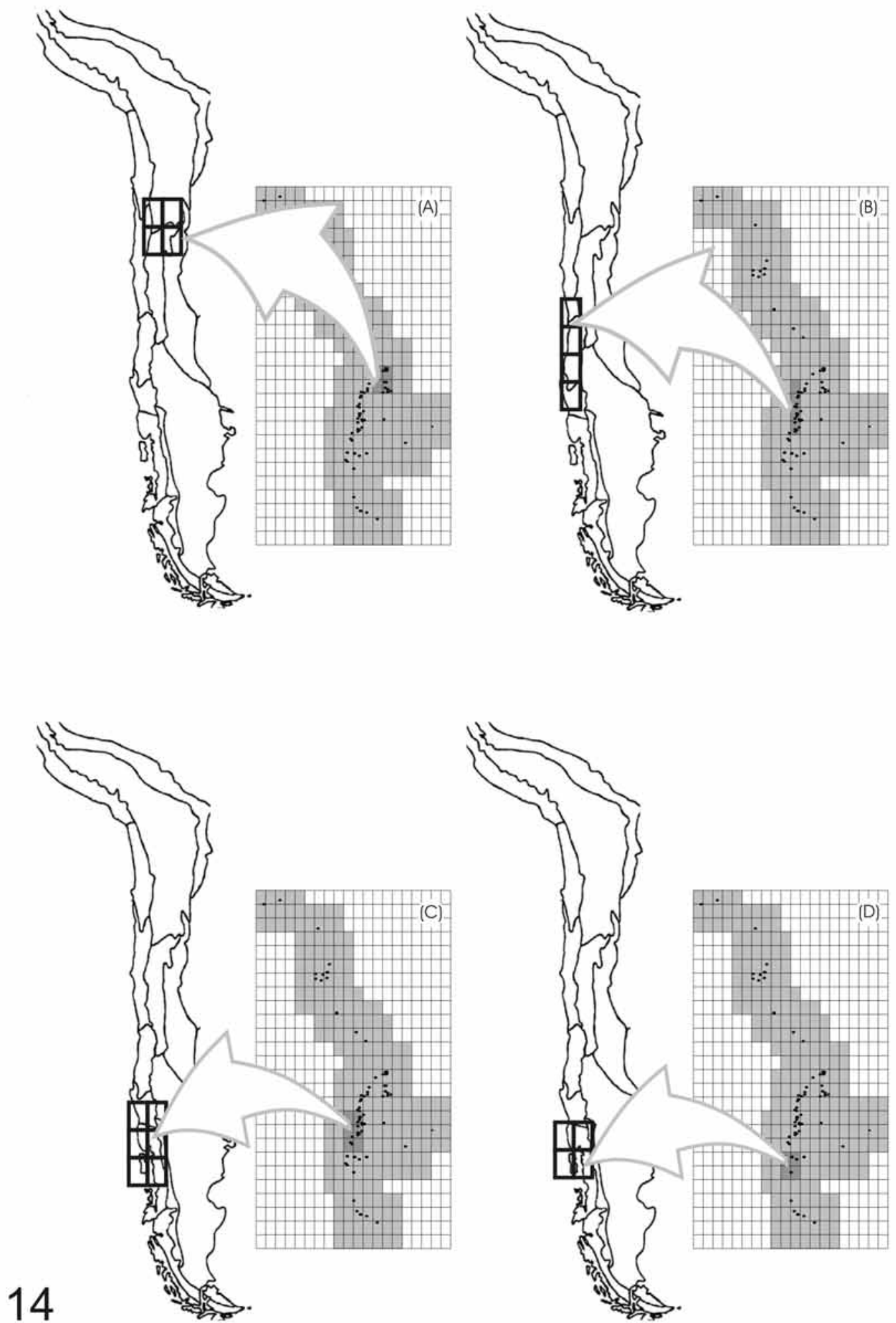

FIGURE 14. Areas of endemism obtained with NDM/VNDM: (A): Puna + Prepuna; (B): Coquimbo / Maule; (C): Maule + Valdivian Forest; (D): Valdivian Forest. 


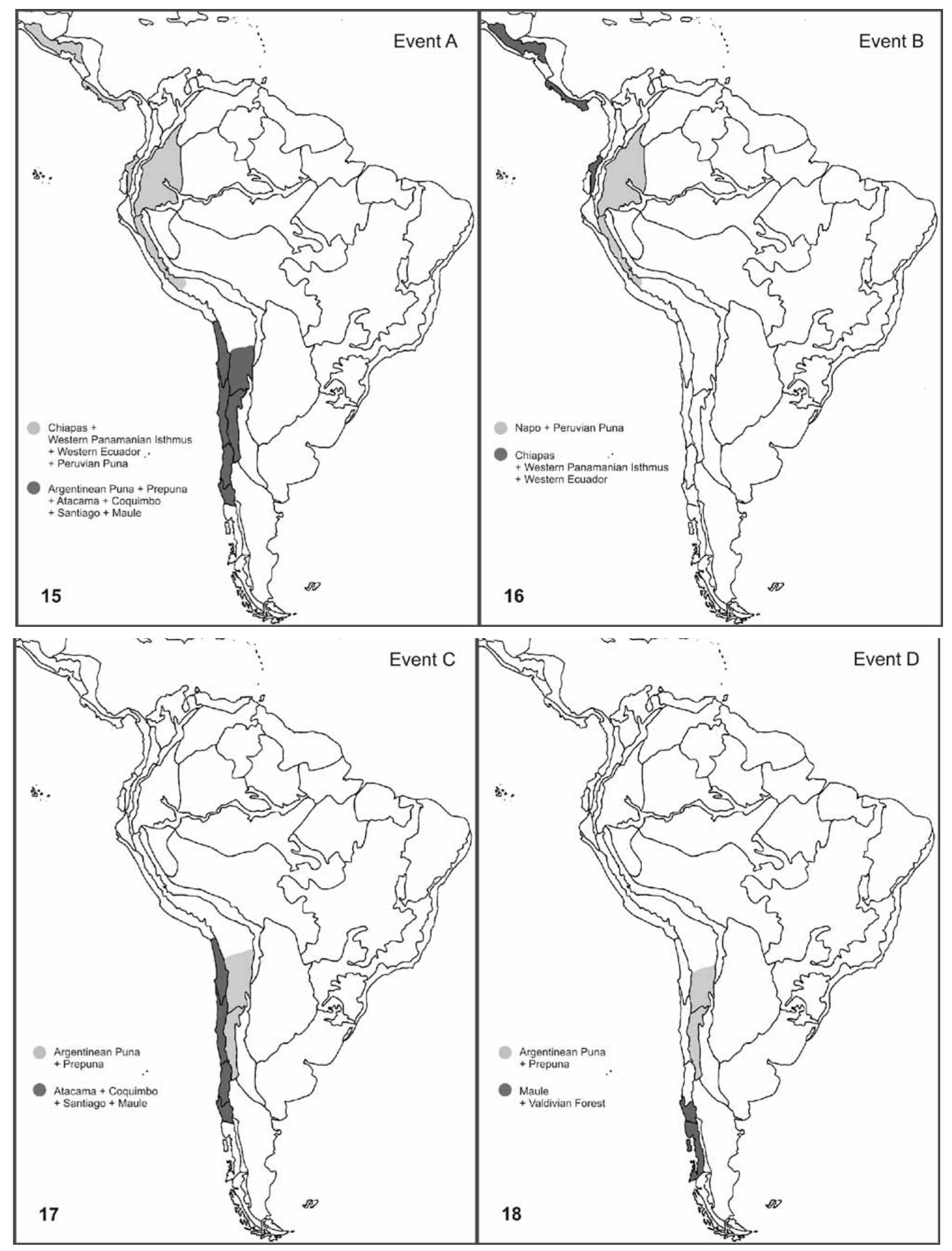

FIGURES 15-18. Vicariant events (A-D). 


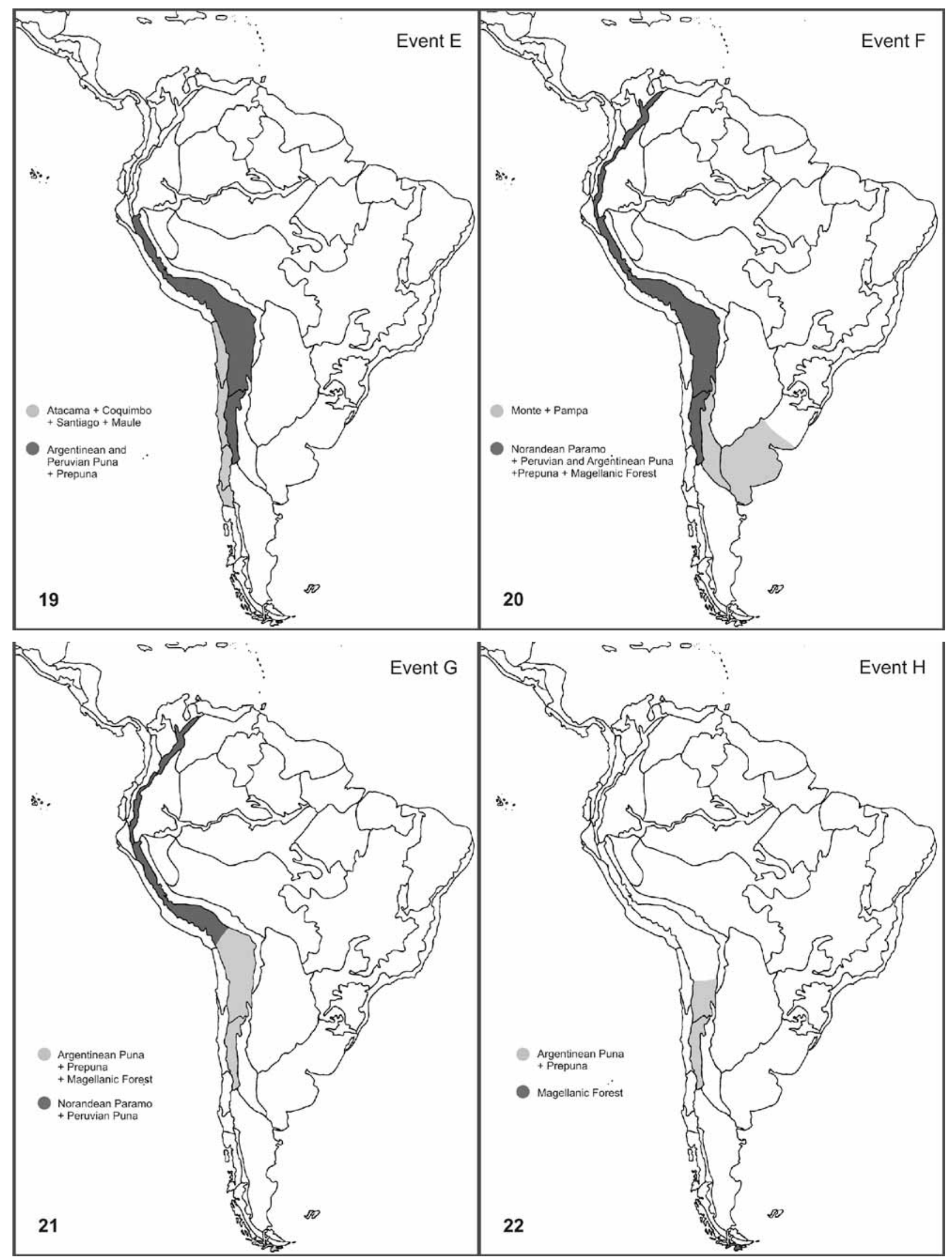

FIGURES 19-22. Vicariant events (E-H). 

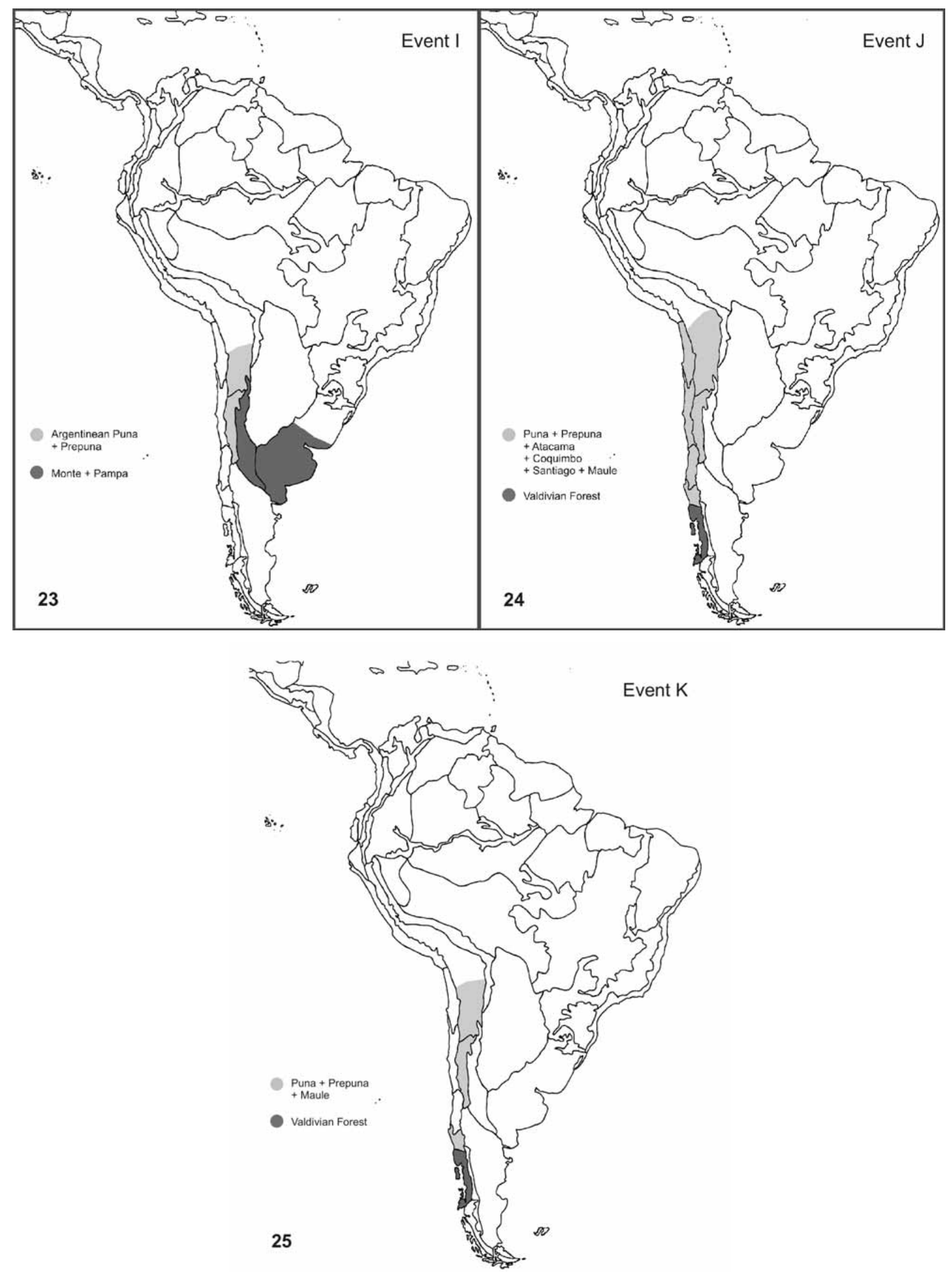

FIGURES 23-25. Vicariant events (I-K). 
According to Morrone's Biogeographic Regions (2004) Pelinoides is present in the Neotropical and Andean Regions, and also in the Transitional South American Zone. In this study we describe four areas of endemism: one corresponding to Transitional South American Zone, and three to the Andean Region. The eleven vicariant events described here involved only the Transitional Zone (one event); the Transitional Zone and the Andean Region (6 events); the Transitional Zone and the Neotropical Region ( 3 events); and the Transitional Zone, and the Neotropical and the Andean regions (one event). Morrone (2004) commented on the relevance of the biotic components that are present in transitional zones. That is the case in event F (Fig.20) that involved almost all the South American Transitional Zone plus the biogeographic province of Pampa (in part) of the Neotropic Region.

Areas of endemism are restricted to the Transitional Zone (Argentinean Puna and Prepuna) and the Andean Region (Coquimbo, Maule and Valdivian Forest), except for the province of Santiago that is between them. (Fig. 27).

Our results are mainly coincident with other works using arthropods (Morrone 1994; Morrone et al, 1997; Roig Juñent \& Coscarón 2001; Roig Juñent \& Flores 2001; Roig Juñent et al 2003; Marino et al 2001); some disagreement between them can probably be ascribed to different methods and taxonomy groups treated in each research project.

\section{Acknowledgments}

This work was supported by grants PICT Nº 12605 FONCYT-BID, PIP No 02567 CONICET, and Consejo de Investigaciones de la Universidad Nacional de Tucumán, Argentina. We wish to thank Juan José Morrone for permission to use his maps and Alberto Bernardino Rojas for georeferences. We also thank Pablo Goloboff, Roberto Menni, Luisa Montivero and reviewers, Wayne Mathis and Thadeus Zatwarnicki, for useful comments and criticisms and Andrés Grosso for the illustrations.

\section{References}

Cresson, E. T. Jr. (1931) Ephydridae. In Diptera of Patagonia and South Chile. 6 (2). British Museum (Natural History), London. 85-116.

Cresson, E. T. Jr. (1934) Descriptions of New Genera and Species of the Dipterous family Ephydridae. XI. Transaction of American Entomological Society, 60, 199-222.

Giribet, G. (2005) Book Reviews: TNT: Tree analysis using New Technology. Systematic Biology, 54, 176-178.

Goloboff, P. (1993) Estimating character weights during tree search. Cladistics, 9, 83-91.

Goloboff, P. (2005) NDM/VNDM programs for identification of areas of endemism. Available from http:// www.zmuc.dk/public/phylogeny/endemism

Goloboff, P. \& Farris, J. (2001) Methods for quick consensus estimation. Cladistics, 17: S26S34.

Goloboff, P., Farris, J., Källersjö, M., Oxelmann, B., Ramirez, M. \& Szumik, C. (2003) Improvements to resampling measures of group support. Cladistics, 19, 324-332.

Goloboff, P., Farris, J. \& Nixon, K. (2005) TNT: Tree analysis using New Technology. ver. 1.0. Available from http:// www.zmuc.dk/public/phylogeny

Hendel, F. (1930) Die Ausbeute der deutschen Chaco-Expedition 1925-1926. Diptera. XIX. Ephydridae. Konowia, 9, (2), 127-155.

Hovenkamp, P. (2004) Review of TNT - Tree Analysis Using New Technology, Version 1.0. Cladistics, 20, 378-383.

Lizarralde de Grosso, M. (1981) El género Pelinoides Cresson en la República Argentina (Diptera-Ephydridae). Neotropica, 27, (77), 93-95.

Lizarralde de Grosso, M. (1989) Ephydridae de la República Argentina. Serie Monográfica y Didáctica, (3), 93 pp. Facultad de Ciencias. Naturales e Instituto Miguel Lillo. Ed. Universidad Nacional de Tucumán.

Lizarralde de Grosso, M. (1998) Ephydridae. In S. Coscarón \& J. J. Morrone (Ed), Biodiversidad de Artropódos Argentinos. La Plata, Argentina, pp 365-373. 
Marino, P. I., Spinelli, G. R. \& Posadas, P. (2001) Distributional Patterns of species od Ceratopogonidae (Diptera) in Southern South America. Biogeographica, 77 (3), 113-122.

Mathis, W. N. (1977) Key of the Neotropical Genera of Parydrinae with a revision of the genus Eleleides Cresson (Diptera: Ephydridae) Proceeding of the Biological Society of Washington, 90, (3), 553-565.

Mathis, W. N. (1985) Studies of Parydrinae (Diptera:Ephydridae), II: A Revision of the Shore Fly Genus Pelinoides Cresson. Smithsonian Contributions to Zoology, (410), 1-46.

Mathis, W. N. \& Zatwarnicki, T. (1995) World Catalog of shore flies (Diptera: Ephydridae). Memoires on Entomology, International. Edit. Gupta, V.K., Associated Publishers, Gainesville, Fl., USA, 423 pp.

Meier, R. \& Ali, F. B. (2005) The newest kid on the parsimony block: TNT (Tree analysis using new technology). Systematic Entomology, 30, 179-182.

Morrone. J. J. (1994). Distributional patterns of species of Rhytirrhinini (Coleoptera: Curculionidae) and the historical relationships of the Andean provinces. Global Ecology and Biogeography Letters. 4, 188-194.

Morrone, J. J. (2001) Biogeografía de América Latina y el Caribe. M \& T. Manuales y Tesis, Sociedad Entomológica Aragonesa, Zaragoza, 3, 148 pp.

Morrone, J. J. (2004) Panbiogeografía, componentes bióticos y zonas de transición. Revista Brasileira de Entomologia, $48,(2), 149-162$.

Morrone, J.J., Katinas, L. \& Crisci, J. V. 1997. A Cladistic Biogeography Analysis of Central Chile. J. Comp. Biol. 2 (1), $25-42$.

Roig Juñent, S. \& Coscarón, S. (2001). Biogeographical History of the Neotropical and Neantartic Simuliidae (Diptera). Rev. Mus. Argentino Cienc. Nat., n.s. 3 (2), 119-134.

Roig Juñent, S. \& Flores, G. E. (2001) Historia Biogeografica de las Áreas Áridas de América del Sur Austral. In J. Llorente Bosquets \& J. J. Morrone (Eds) Introducción a la Biogeografía en Latinoamérica: Teorías, conceptos, métodos y aplicaciones. México, Las Prensas de Ciencias, UNAM pp 257-266.

Roig Juñent, S., Flores, G. E \& Mattoni, C. (2003) Consideraciones Biogeográficas de la Precordillera (Argentina), con Base en Artrópodos Epógeos. In J. J. Morrone \& J. L. Llorente Busquets (Ed), Una perspectiva Latinoamericana de la Biogeografía. México, Las Prensas de Ciencias, UNAM pp. 275-288.

Ronquist, F. (1994) Ancestral areas and parsimony. Systematic Biology, 43, 267-274.

Szumik, C., Cuezzo, F., Goloboff, P. \& Chalup, A. (2002) An optimality criterion to determine areas of endemisms. Systematic Biology, 51, 806-816.

Szumik, C. \& Goloboff, P. (2004) Areas of Endemism: An Improved Optimality Criterion. Systematic Biology, 53, 968977.

Wirth, W.W. (1968) Ephydridae. In N. Papavero (Ed), A Catalogue of the Diptera of the Americas South of the United States. Departamento de Zoologia, Sao Paulo, Brasil, pp. 1-43.

Zatwarnicki, T. (1992) A New Classification of Ephydridae Based on Phylogenetic Reconstructions (Diptera: Cyclorrhapha). Genus, 3, (2), 65-119. 
Appendix 1. List of characters used in the cladistic analysis. Characters 1, 2, 4, 7, 9, 10, 12, 13, 15, 20, 21, 24, 25, 30, 35, 36 and 37 are uninformative; they are included here to show on the cladograms the list of autapomorphies of Pelinoides. Characters are codified as additive.

Head:

0. Vestiture of Mesofrons. (0) very sparsely microtomentose; (1) mostly sparcely microtomentose; (2) densely sparsely microtomentose; (3) moderately densely microtomentose; (4) densely microtomentose.

1. Mesofrons with a large bare area. (0) no; (1) yes.

2. Fronto-orbital bristles conspicuous. (0) no; (1) yes.

3. Antenna coloration. (0) black to dark brown; (1) same to 0 but first flagellomere yellowish to orange; (2) orange yellowish.

4. Arista bearing small hairs. (0) yes; (1) no, with long hairs.

5. Arista with dorsally branching rays. (0) long; (1) short; (2) absent.

6. Dorso-apical angle of first flagellomere. (0) broadly rounded; (1) angulated.

7. Face beyond anterior margin. (0) flat; (1) convex.

8. Midface coloration. (0) bluish grey; (1) white silvery; (2) shiny white; (3) brownish white (4) yellowish.

9. Epistomal margin of face broadly emarginate medially. (0) yes; (1) no.

10. Clypeus. (0) conspicuous; (1) inconspicuous.

11. Gena coloration. (0) yellowish white; (1) silvery white; (2) white to grey (3) brownish white.

12. Eyes prominent. (0) yes; (1) no.

13. Eyes. (0) glabrous; (1) pilose.

14. Palpus coloration. (0) black brownish; (1) yellowish brown; (2) yellow to orange; (3) yellow.

Thorax:

15. General coloration. (0) brown to nearly black; (1) pale grey yellowish.

16. Vestiture of the mesonotum. (0) very densely microtomentose; (1) moderately densely microtomentose; (2) sparsely microtomentose; (3) very sparsely microtomentose to bare.

17. Mesonotum coloration. (0) brown to mostly black; (1) mostly brown (2) mostly brown to grayish brown; (3) olivaceous to brown; (4) grey to golden brown.

Stripes of scutum:

18. Stripes of the scutum. (0) absent; (1) present.

19. Stripes of scutum coloration. (0) golden brown; (1) dark brown; (2) greyish; (3) brownish; (4) blackish.

20. Median stripe. (0) present; (1) absent.

21. Intraalar stripes. (0) present; (1) absent.

Scutellum:

22. Basolateral margins of scutellum. (0) no microtomentose; (1) slightly velvety microtomentose; (2) densely microtomentose.

23. Posteroblique angle of scutellum appearing velvety black. (0) no; (1) yes.

24. Presutural bristles. (0) conspicuous; (1) inconspicuous.

25. Acrostichal setulae. (0) conspicuous; (1) small, inconspicuous.

26. Dorsocentrals bristles. (0) five; (1) three or four; (2) two; (3) one.

Halters and Wings:

27. Knob of halter. (0) blackish brown; (1) brownish; (2) yellowish slightly brownish; (3) whitish yellowish.

28. Stem of halter. (0) yellowish; (1) yellowish brown.

29. Wing. (0) hyaline; (1) with clouded areas; (2) very lightly infumose.

30. Wing vein 1. (0) rather swollen and black; (1) no swollen and black.

Legs:

31. Femora and tibia. (0) blackish brown; (1) yellowish brown; (2) slightly yellow.

Abdomen:

32. Tergum coloration. (0) mostly blackish; (1) mostly brown.

33. Tergum microtomentose. (0) yes; (1) partially shiny.

34. Tergum microtomentose respect to mesonotum. (0) more; (1) equal; (2) slightly less; (3) less.

Male genitalia: 
35. Epandrium. (0) distally tapered; (1) distally round.

36. Gonite. (0) with reduced setulae; (1) setose.

37. Long setae inserted at connection of gonite with hypandrium. (0) present; (1) absent.

Codifications of the mesonotum stripes pattern (Fig. 1-8). Of course when a codification was analysed with the program TNT the other was deactivated.

Codification I:

38. (Additive). (0) without stripes; (1) with stripes laterad to acrostichal tracks (2) same as 1 but with partial stripes laterad to dorsocentrals tracks; (3) same as 1 but with stripes laterad to dorsocentral tracks; (4) stripes anteriad to either side of acrostichal tracks; (5) stripes through acrostichal tracks and on lateral margin; (6) stripes through acrostichal and dorsocentral tracks; (7) stripes between dorsocentral and intra-alar tracks.

\section{Codification II:}

39. Stripes laterad to acrostichal tracks: (0) absent; (1) present.

40. Stripes through acrostichal tracks: (0) present; (1) absent.

41. Partial stripes laterad to dorsocentral tracks: (0) present; (1) absent.

42. Stripes laterad to dorsocentral tracks: (0) present; (0) absent.

43. Stripes anteriad on either side of acrostichal tracks: (0) present; (1) absent.

44. Stripes on lateral margin: (0) present; (1) absent. 
Appendix 2. Morphological data matrix.

1

2

3

4

Nostima elegantula

012345678901234567890123456789012345678901234

401210014111113104130020112210010231107011011

300101100000001001101100000102121030011011111 100101100001003014111100113302111030016001011 $40000200100100002 ? 1211111134011001 ? 0014011101$ 200002201001000030121131113300100000014011101 200002201001000000141131113300100030010111111 100002201001000030021131113300100000010111111 000002201001000020121131113300100000014011101 Pelinoides pallipes Pelinoides cyclocerus Pelinoides sulcatus Pelinoides pullus Pelinoides amblys Pelinoides chiloensis Pelinoides nigrihalteratus Pelinoides phaeopleurus Pelinoides australis Pelinoides chilensis Pelinoides colerus Pelinoides flavipalpus Pelinoides flinti Pelinoides phaeonotus Pelinoides fuscus Pelinoides obscurus Pelinoides opacus Pelinoides penai Pelinoides unctus Pelinoides pruinosus 000002201001000020131120113000100000015001110 200002201001000000131120113300100010015001110 000002201001000020131131113210100010015001110 200002201001000002141131113300100030013011011 000002201001000002121131113300101010013011011 300102203003004002121120111300101010013011011 410002201001000001121131113300100020013011011 100002202002000021021131113300100030010111111 300002201001000001121131113300101010013011011 $40000220100100000212113 ? 113100101010011011111$ 300102201001002013121131113300101010016001011 300002201001000001121131113300101010013011011 400102201001002001121131113300101010012010111 400102201001002001121120113300101030012010111 
Appendix 3. Binary data matrix of presence and absence of species on a cell grid of $26 \times 20\left(2^{\circ} \times 3^{\circ}\right)$. The rows are the grid cells, the numbers indicate the position of the cell in the grid, e.g. cell $0-1$ is located in the row 0 and columm 1 . The columms are the species of Pelinoides: 0, P. amblys; 1, P. andinus; 2, P. australis; 3, P. chilensis; 4, P. chiloensis; 5, P. colerus; 6, P. cyclocerus; 7, P. flavipalpus; 8, P. flinti; 9, P. fuscus; 10, P. nigrihalteratus; 11, P. obscurus; 12, P. opacus; 13, P. pallipes; 14, P. penai; 15, P. phaenotus; 16, P. phaeopleurus; 17, P. pruinosus; 18, P. pullus; 19, P. sulcatus; 20, P. unctus.

012345678901234567890

0-0 000000000000010000000

0-1 000000000000010000000

$0-2 \quad 000000000000010000000$

0-3 000000000000020000000

1-0 000000000000010000000

1-1 000000000000010000000

$1-2 \quad 000000000000020000000$

1-3 000000000000020000000

2-5 000000000000010000000

2-6 000000000000010000000

2-7 000000000000020000000

3-5 000000000000020000000

3-6 000000000000020000000

3-7 000000000000020000000

4-6 020000000000000000000

4-7 020000000000000000000

4-8 020000000000000000000

5-5 000000000000010000000

5-6 010000000001010000000

5-7 010000000001000000000

5-8 020000000000000000000

6-5 000000000000010000000

$6-6 \quad 010000000001010000000$

6-7 010000000001010000000

6-8 020000000000000000000

7-5 000000000000020000000

$7-6 \quad 000000000000020000000$

7-7 000000000000020000000

$8-7 \quad 010000000000000000000$

8-8 010000000000000000000

$8-9 \quad 020000000000000000000$

9-7 010000000000000000000

$9-8 \quad 010000000000000000000$

9-9 022000000002000000000

9-10 002000000002000000000

9-11002000000002000000000

$10-9001000000001000000000$
012345678901234567890

012345678901234567890

10-10 001000000001000000000 17-12 000000000000000000001

10-11 $002000000001000000000 \quad 17-13 \quad 000000000000000000001$

10-12 $000000000002000000000 \quad 17-17 \quad 000000000000000000001$

11-10 $000000000001000000000 \quad 17-18 \quad 000000000000000000001$

11-11 $000000000001000000000 \quad 18-8 \quad 000000000020000020020$

11-12 $000000000002000000000 \quad 18-9 \quad 201100000020000010010$

$12-12000000000000000200210 \quad 18-10 \quad 201100000020002010010$

12-13 $000000000000000200210 \quad 18-11202000000020002020020$

12-14 $00000000000000000022018-12002000000020000000000$

13-10 $000000000000000000020 \quad 18-14000000000000000000001$

13-11 $000000000000000000010 \quad 18-15000000000000000000001$

13-12 $000001000000000102110 \quad 18-16000000000000000000002$

13-13 $000001000000000102110 \quad 19-8 \quad 000010000010000010010$

13-14 $000002000000000002220 \quad 19-9 \quad 001010200010000010010$

14-9 $000200020000000000000 \quad 19-10 \quad 001020200010000020010$

14-10 $000100020000000000020 \quad 19-11001000000010000000010$

14-11 $000100020000000000010 \quad 19-12 \quad 002000000020000000000$

14-12 $000201000100000001010 \quad 19-14 \quad 000000000000000000002$

14-13 $000001000100100001010 \quad 19-15000000000000000000002$

14-14 $000002000100100002020 \quad 19-16 \quad 000000000000000000002$

15-9 $002200020000000000000 \quad 20-8 \quad 000010000000000000010$

15-10 $001102010000000000020 \quad 20-9 \quad 002010100000000000010$

15-11 $002102010000000000020 \quad 20-10 \quad 002020100000000000010$

15-12 $000202000100000000020 \quad 20-11002000000000000000020$

15-13 $000001000100100000020 \quad 22-9 \quad 000000002000000000010$

15-14 000002000200100000020 22-10 000000002000000000010

16-9 $002200020000002000020 \quad 22-11 \quad 000000002000000000000$

16-10 $001101010000001000010 \quad 23-9 \quad 000000001000000000020$

16-11 $001101010000001000010 \quad 23-10 \quad 000000001000000000020$

16-12 $000000000000000000001 \quad 23-11000000001000000000000$

16-13 $000000000000000000001 \quad 23-12 \quad 000000001000000000000$

$16-17000000000000000000002 \quad 23-13000000002000000000000$

16-18 $000000000000000000002 \quad 24-9 \quad 000000002000000000000$

17-8 $000000000000000000020 \quad 24-10 \quad 000000002000000000000$

17-9 202200000000002010020 24-11 000000002000000000000

17-10 $101100000000001010010 \quad 24-12000000001000000000000$

17-11 201100000000001010010 24-13 000000002000000000000 